\title{
Botryoid-Type Embryonal Rhabdomyosarcoma
}

National Cancer Institute

\section{Source}

National Cancer Institute. Botryoid-Type Embryonal Rhabdomyosarcoma. NCI

Thesaurus. Code C9150.

A morphologic variant of embryonal rhabdomyosarcoma arising from organs with a mucosal epithelial surface. It is characterized by the formation of a cambium layer in the affected tissue and polypoid nodules within an abundant myxoid stroma. 